\title{
The Impact of Local Labor Market Conditions on Work and Welfare Decisions: Revisiting an Old Question Using New Data ${ }^{1}$
}

\author{
November 2007 \\ Chris M. Herbst \\ Assistant Professor \\ School of Public Affairs \\ Arizona State University \\ David W. Stevens \\ Executive Director \\ The Jacob France Institute \\ University of Baltimore
}

\begin{abstract}
Using Maryland administrative data between 1996 and 2005, this paper examines the impact of local labor market conditions on work and welfare use among single mothers. Our estimates rely on the new Census Bureau Quarterly Workforce Indicators database, which provides county-level economic indicators filtered by industry, gender, and age-group. We specify a multinomial choice model to estimate the effects of local labor market variables, demographic characteristics, and controls for unobserved heterogeneity on the full set of workwelfare combinations. The results indicate that lower unemployment rates and increased new hires and new hires' earnings in key industries increase the likelihood that women choose alternatives that include work. African American women and those with fewer years of education respond differently to changing economic conditions. Our results are robust to controls for fixed effects, county-specific time trends, and endogenous migration.
\end{abstract}

\footnotetext{
${ }^{1}$ Please direct all correspondence to Chris.Herbst@asu.edu. Both authors are grateful for helpful comments from Richard Larson, Jane Staveley, and Peter Mueser. Early versions of this paper benefited from the insightful comments of conference participants at the $10^{\text {th }}$ Annual ACF/OPRE Welfare Research and Evaluation Conference and the National Association for Welfare Research and Statistics (NAWRS) conference. We are also grateful for assistance provided by John Janak, who prepared the data files.
} 


\section{Introduction}

With the passage of the Personal Responsibility and Work Opportunity Reconciliation Act (PRWORA) in 1996, the focus of state welfare offices shifted from providing cash assistance to helping disadvantaged individuals enter the labor force. Recent research evaluating single mothers' transition from welfare to work has stressed the role of supply-side side factors such as human capital development and marriage decisions, as well as the flurry of social policy reforms implemented throughout the 1990s. Many of these studies treat policy reforms as nuanced and multidimensional explanations of work-welfare decisions, and it is now common to include detailed measures of welfare reform, the EITC, and child care subsidies in such models.

Economic conditions are also expected to influence work and welfare use, both through the availability of jobs and the generosity of wage offers. However, little is known about the effects of demand-side factors. What we do know comes from the literature's nearly exclusive focus on the state unemployment rate. Exceptions to the use of this measure are rare, but they include aggregate employment growth rates (Schoeni \& Blank, 2000), median wages (Wallace \& Blank, 1999), 20th percentile wages (Wallace \& Blank, 1999; Fang \& Keane, 2004); average earnings in various industries (Hoynes, 2000), gross job flows (Bartik \& Eberts, 1999) and employment-to-population ratios (Hoynes, 2000).

Studies matching micro data with the unemployment rate or an employment-based alternative suffer from a number of drawbacks. Perhaps the most important constraint is the lack of sub-state-level geographic identifiers in survey datasets. Confidentiality concerns typically preclude identification of labor markets smaller than the state, thereby masking potentially large within-state variation in economic conditions. Moreover, survey data generally provide small samples of single mothers or welfare recipients, making it difficult to 
determine how labor market conditions impact sub-groups of important populations. Finally, the collection of annual data on employment and welfare use prevents researchers from analyzing short-term labor demand shocks. These shortcomings mean that previous studies have defined local labor markets imprecisely, and it is not surprising that results from this body of work are inconclusive and suggest a small role for the unemployment rate and many of its alternatives.

Nevertheless, it has become increasingly important to understand the relationship between labor demand conditions and work-welfare outcomes. Funding for cash assistance has changed from an open-ended entitlement to a close-ended block, which essentially means that states now face greater financial risks as labor market conditions fluctuate. Added to this are strict work requirements and time limits for welfare recipients that operate in the same manner across all economic conditions. Many states have also begun experimenting with policies that deter potential welfare recipients from receiving aid. Currently, 20 states mandate job search activities at the time of application, and 30 states operate cash diversion programs. The work-first nature of these policies relies heavily on the ability of local labor markets to absorb welfare recipients, or at least encourage such individuals to seek economic well-being outside the welfare system.

This study merges administrative data for the state of Maryland with new indicators of county-level labor market conditions to provide substantially improved estimates of the effects of economic conditions on employment and welfare use among single mothers. The micro data provide complete (quarterly) employment and (monthly) welfare histories for a sample of women over the period 1996 to 2005 . We draw the labor market data from the Census Bureau's Quarterly Workforce Indicators (QWI) series, a partnership between the Bureau, 41 states, and the District of Columbia to disseminate detailed information on local 
labor market conditions. Among the distinctive features of the QWI are industry-specific measures of county labor market conditions that can be further disaggregated by gender and age-group. A key advantage of the QWI series is the opportunity to replicate local-level analyses across most states. We consider several measures of economic conditions including the unemployment rate, new hires and new hires' earnings in common destination industries, and job flows. We specify a multinomial choice model to estimate the effects of gender- and age-specific labor market variables, demographic characteristics, and controls for unobserved heterogeneity on the full set of work-welfare combinations. Our study sheds new light on how economic conditions influence two groups with important policy implications: women who are neither working nor receiving welfare and women who are working without welfare.

Results suggest that women respond to labor market conditions in ways predicted by standard economic models. Specifically, we find that increased new hires and new hires' earnings in key industries increase the likelihood that women choose alternatives that include work, even if women work in conjunction with welfare receipt. Contrary to previous research, we find that single mothers' work-welfare decisions are responsive to changes in the unemployment rate. We also show that African American women and those with less than a high school degree are more sensitive to labor market opportunities when considering employment and welfare use simultaneously, while white women and those who completed high school are more responsive as they move into work without welfare. Our main results are robust to alternative specifications that include controls for unobserved relocation choices.

The remainder of this paper proceeds as follows. Section II briefly summarizes the relevant empirical literature, while Section IIII provides a conceptual framework within which the importance of labor market conditions is highlighted. Section IV introduces the 
administrative and QWI data sources and presents the empirical model. Results are discussed in section V, and section VI concludes.

\section{Previous Research on the Impact of Labor Market Conditions}

There are many ways to organize the literature on the effects of economic conditions, but it is useful for the purposes of this paper to consider separately studies using state- and county-level measures of labor market opportunities.

Empirical work using state-level measures is voluminous and can be further classified by whether such measures explain aggregate movements in welfare caseloads or individual reports of work and welfare use from survey datasets. The majority of papers examining national or state caseloads use the unemployment rate (Bartik \& Eberts, 1999; Blank, 2001; CEA, 1997; 1999; Figlio \& Ziliak, 1999; Levine \& Whitmore, 1998; Moffitt, 1999; Schiller, 1999; Wallace \& Blank, 1999; Ziliak, Figlio, Davis \& Connelly, 2000). Results from these studies are remarkably consistent, finding that a one percentage point increase in the unemployment rate increases welfare caseloads by five to seven percent. A noteworthy exception is Klerman and Haider's (2004) stock-flow analysis, which finds effect sizes between 12 and 47 percent. Overall, these studies indicate that changes in economic conditions explain 20 to 80 percent of the pre- and post-TANF caseload change throughout the 1990s. A few caseload studies have experimented with alternative measures of state labor market conditions, such as gross job flows (Bartik \& Eberts, 1999), minimum wages (CEA, 1999), median and $20^{\text {th }}$ percentile wages (Wallace \& Blank, 1999), and wage premiums (Bartik \& Eberts, 1999). There is weaker consensus about the influence of these factors, but many studies continue to find significant, albeit smaller, effects of employment-based alternatives. 
These early caseload studies were then modified by researchers using individual-level data from large, nationally representative surveys. ${ }^{2}$ The most common methodological approach is to pool time series of cross-sectional samples of single mothers and estimate a discrete choice employment or welfare participation equation as a function of individual characteristics, social policy reforms, labor market conditions, and controls for unobserved heterogeneity (Fang \& Keane, 2004; Grogger, 2003; 2004a; Herbst, 2007; Looney, 2005; Meyer \& Rosenbaum, 2001; Noonan, Smith, \& Corcoran, 2005; O’Neil \& Hill, 2001; Schoeni \& Blank, 2000). As with caseload studies, the preponderance of this research uses the unemployment rate as the key indicator of state labor market conditions. Estimates suggest that a one percentage point increase in the unemployment rate is expected to decrease employment by 0.5 to 2.0 percentage points and increase welfare use by one percentage point. These point estimates imply that the unemployment rate accounts for approximately 25 percent of single mothers' employment growth and 20 percent of the decline in welfare use throughout the 1990s. ${ }^{3}$

Turning to the studies that examine county-level indicators of labor market opportunities, one finds that most of this research is embedded in the welfare dynamics tradition. Several studies analyze the impact of county-level unemployment rates on welfare exits (Blank, 1989; Fitzgerald, 1995; Harris, 1993), while others investigate returns to welfare (Harris, 1996; Pavetti, 1993; Mueser, Stevens, \& Troske, 2007) None of these studies find large or statistically significant effects of local labor market conditions. A noteworthy exception is Hoynes (2000), who uses administrative data from California between 1987 and

\footnotetext{
${ }^{2}$ For thorough reviews of this research, see Blank (2002) and Grogger and Karoly (2005).

${ }^{3}$ Analyses of exits from and reentry to welfare are also relevant to this study. Early research on welfare dynamics consistently uses either the state unemployment rate or average wages as the principal controls for economic conditions (Bane \& Ellwood, 1983; Blank \& Ruggles, 1996; Fitzgerald, 1991; Hoynes \& MaCurdy, 1994). These studies generally find statistically insignificant effects of labor market variables. More recent work by Hofferth, Stanhope, and Harris (2002; 2005) and Grogger (2004b) indicate mixed results.
} 
1992 to analyze several county-level labor market variables on exits from and reentry to welfare. Specifically, the author considers total UI covered employment, employment in the retail and service sectors, earnings, and employment-to-population ratios. Hoynes' results suggest that a 10 percent increase in employment or a 3.5 percent increase in employment-topopulation ratios is associated with a 7 to 15 percent increase in the likelihood of exiting welfare. Earnings are found to increase exit probabilities by a smaller amount (five percent). Labor market conditions are also highly correlated with reentry.

By merging administrative data with a new set of county-level labor market indicators, we improve upon previous research in a number of ways. Our sample size is large enough to facilitate comparisons across sub-groups of welfare recipients including racial/ethnic groups, educational levels, and urban-rural designations. Second, the use of administrative data allows us to more accurately measure employment and welfare participation than studies relying on self-reports, which suffer from recall bias, stigma effects, and other problems associated with misinterpreting survey questions. ${ }^{4}$ A related problem with survey data is the well known underreporting of program participation, which has worsened over time. ${ }^{5,6}$ Third, identification of employment and welfare use on a quarterly basis is preferable to annual measures. With quarterly data we are able to capture the effects of short-term shocks to local

\footnotetext{
${ }^{4}$ Misreporting due to stigma is an important challenge for researchers. Anecdotal evidence from Maryland points to substantial geographic variation in welfare office culture. Local welfare office employees describe sub-state differences in attitudes about welfare dependency, noting that residents in the far western panhandle of the State are more likely to associate a stigma with dependence than might be found in mid-Maryland or among seasonal employees on the eastern shore.

${ }^{5}$ Underreporting program participation in the CPS is especially problematic. A recent analysis of California's Medicaid and welfare programs finds that the CPS undercounts Medicaid by 30 percent as compared to administrative data, while welfare undercounts are in the range of 50 to 60 percent (Klerman, Ringel, Roth, 2005). This problem pervades other surveys and programs as well. For example, a study of the Maryland Food Stamp program found the published estimate of food stamp receipt from the U.S Census Bureau's American Community Survey, Supplementary Survey for 2001 (ACS/SS01) was substantially lower than the count from the State's administrative records and most of the discrepancy of about 75,000 food stamp households was due to underreporting (Taeuber, Resnick, Love, Staveley, Wilde, \& Larson, 2004).

${ }^{6}$ Another problem with longitudinal survey data is "seaming," or the propensity to observe few employment and/or welfare transitions within waves of data collection. Rather, most transitions are observed to occur between waves. Grogger's (2004b) analysis of SIPP data, for example, finds that 70 percent of welfare exits in the 1996 panel occur between waves.
} 
labor markets as well as observe employment and welfare spells lasting only short periods. ${ }^{7}$

Finally, our data cover a substantially longer time period (1996-2005, or 40 quarters) than

longitudinal survey data would allow. ${ }^{8}$ Hence, we are able to examine the effects of labor market conditions during periods of economic growth and contraction.

\section{Conceptual Framework for Understanding the Impact of Labor Market Conditions}

To understand how local labor markets influence work-welfare decisions, we note that previous research finds changes in employment and marital status as key events preceding transitions to and from welfare (Bane \& Ellwood, 1983; Blank \& Ruggles, 1996; Harris, 1993; Pavetti, 1993). The economic environment in which mothers operate is assumed to alter the costs and benefits associated with work and marriage, thereby influencing underlying preferences for cash assistance. Labor market opportunities influence employment incentives directly, but the interaction of economic conditions and marriage behavior is an indirect path to altering employment incentives. We draw on insights from Hoynes (2000) as we consider both alternatives below.

Standard labor supply models suggest that the decision to work is a utility maximization problem in which individuals choose quantities of leisure and levels of government assistance (e.g., welfare, food stamps, and Medicaid) subject to budget and time constraints. Arguments in the budget constraint include the expected wage offer, welfare grant amounts, and other sources of non-wage income. Therefore, under reasonable conditions, utility can be stated as a linear function of leisure time, all sources of income, and

\footnotetext{
${ }^{7}$ The Panel Study of Income Dynamics (PSID) is the primary survey dataset used in studies of welfare dynamics. However, it captures only annual welfare spells and allows for only state-level geographic identifiers. The National Longitudinal Survey of Youth (NLSY) provides monthly data, but only for a small fraction of the sample. It does, however, allow users to append county-level variables to the dataset. The other option for analysts is the Survey of Income and Program Participation (SIPP). While the SIPP provides monthly employment and welfare data, it is hampered by the fact that sample members remain in the sample for relatively short periods, between 24 months and 48 months. The SIPP does not provide access to county-level identifiers.

${ }^{8}$ Our paper is not the first to use administrative data to examine the work behavior of single mothers after the implementation of welfare reform. A recent paper by Mueser, Stevens, and Troske (2007) examines three cohorts of women in Maryland and Missouri using the county-level unemployment rate as the primary control for local economic conditions.
} 
stigma associated with participation in means-tested programs. The probability that a single mother works is the probability that expected utility while working exceeds the expected utility of not working. A testable implication of this model is that local labor markets influence the relative utility from working in two ways. First, mothers operating in high employment growth areas experience fewer structural constraints on finding jobs, thereby increasing the likelihood of employment. Second, conditional on finding a job, increased wage offers make work relatively more attractive than welfare, also increasing the likelihood of employment.

Critical to our study is that employment and wages are measured for key destination industries among welfare recipients. Retail trade and the service sectors hire large numbers of Maryland welfare leavers. A recent study by Mueser, Stevens, and Troske (2007) found that these two industries in the period following welfare reform account for 73 to 82 percent of the jobs taken by individuals in the first quarter after leaving welfare. Eating and drinking places and department and grocery stores alone account for 14 to 22 percent of the destination jobs. Therefore, it is important that labor demand in these industries is strong enough to encourage welfare recipients to enter the labor force.

Economic models of marriage suggest that individuals marry when the anticipated utility from entering this state exceeds the utility of remaining single (Becker, 1981). The utility of marriage is typically stated as a function of the individual's earnings potential, the spouse's earnings, and sources of non-wage income including means-tested cash assistance. The model yields ambiguous predictions regarding the impact of own earnings, and thus local labor market conditions, on marriage incentives. Increased earnings could make marriage less attractive through an "independence effect," or it could make marriage more attractive 
through a "stabilizing effect" (Becker, 1973). ${ }^{9}$ However, as long as single women regard marriage as an alternative to cash assistance, improved labor market opportunities are expected to increase the likelihood of employment and reduce welfare use by increasing job stability and wage offers.

\section{Data Sources and Empirical Implementation}

\section{Administrative Micro-Data}

To illustrate the usefulness of the new economic measures, we use administrative data to carefully define a sample of women whose characteristics have been the focus of recent welfare reforms. Our starting point was the universe of AFDC/TANF case-head recipients in Maryland. From this population we selected women born in 1977 with a valid Social Security Number issued in the State. ${ }^{10}$ We then extracted monthly welfare histories for these women between 1996 and 2005, so that in effect we are able to follow individuals between ages 19 and 28. For reasons explained below, women in our sample must have received at least one month of welfare during the last four years of the 10-year observation period. ${ }^{11}$ Our final analysis sample consists of 1,712 women, providing 68,480 person-quarter combinations.

Sample members were then matched to quarterly wage record data from Maryland's Unemployment Insurance (UI) program. Individuals in covered jobs are coded as being employed if positive earnings are reported by an employer in a given quarter. While the overwhelming majority of jobs are covered by the UI system, we necessarily miss self-

\footnotetext{
${ }^{9}$ Empirical work on the effects of labor market conditions suggests that increased earnings is negatively related to marriage among single women, indicative of the independence effect, but is positively related to marriage among unmarried men, indicative of the stabilizing effect (Blau, Khan, \& Waldfogel, 2000).

${ }^{10}$ The SSN criterion serves as a proxy for women's residence in the state during the observation period, which would be unknown when not found in the welfare or employment administrative file. In addition, we calculate that 71.4 percent of the sample received TANF or appeared in a quarterly UI wage report, or both, in 1996 and 2005. Therefore, we are confident that a large majority of women with a valid SSN issued in Maryland were present in the State at the beginning and end of the 10 -year observation period.

${ }^{11}$ In other words, to be included in the sample women must be observed receiving welfare for at least one month between January 2002 and December 2005. Of course, we retained sample members who also received welfare in any month prior to this period.
} 
employment, informal employment, and those employed outside the State and by the Federal Government. This would be a concern for some groups of Maryland workers, given the concentration of residents living close to the District of Columbia. However, most of the State's welfare recipients live in Baltimore City and Baltimore County, so we do not anticipate that many of these individuals commute to jobs outside the State. ${ }^{12}$

The 1977 birth-year criterion is chosen so that the implementation of welfare reform in Maryland coincides with sample members being age-eligible to receive cash assistance as a case-head. ${ }^{13}$ This approach is taken for several reasons. First, we are interested in the impact of labor market opportunities for women entering their prime welfare-receiving years during the transition to a work-first welfare policy. Women in this age-group comprise about 61 percent of Maryland's TANF caseload (DHHS, 2006). Understanding the relationship between economic conditions and work-welfare outcomes for young women is therefore crucial from a policy perspective. Second, in a lifecycle context, the availability of labor market opportunities for young women could be important predictors of work and welfare use in subsequent years. Finally, restricting the observation period to the post-TANF era leads to a cleaner analysis of the effects of labor market conditions. Given that all sample members are "exposed" to welfare reform, it obviates the need to account for these policy changes in the model.

Although the micro-data are well suited for this analysis, they have some drawbacks. First, a common issue for studies using administrative data is that demographic information

\footnotetext{
${ }^{12}$ As of 2004, 66 percent of Maryland's welfare recipients filed for benefits in Baltimore City or Baltimore County, while just 10 percent filed in Prince George's County, a jurisdiction adjacent to the District of Columbia. Furthermore, a recent report found that of Maryland's employed welfare leavers between 2003:Q1 and 2004:Q2, only four to five percent were employed in surrounding states and less than one percent were employed by the federal government and the military (Jacob France Institute, 2005). Therefore, the overwhelming majority of employed welfare leavers are working inside Maryland.

${ }^{13}$ Because women in our sample were born in 1977, they turned 19 sometime during the first year of the study. These women were eligible to receive welfare as case-heads.
} 
on welfare recipients is limited and observed only when individuals receive cash assistance. ${ }^{14}$

Second, since samples based on administrative data are actually samples of welfare recipients (rather than all single mothers), women are selected on the basis of previous or future interactions with the welfare system. We deal with these data limitations by creating a sample of women who received welfare between 2002 and 2005, when full demographic information is available in Maryland's administrative file. ${ }^{15}$ Finally, the advantages associated with the coincident timing of welfare reform and age-eligibility of sample members must be weighed against the drawbacks of a narrowly defined sample. In particular, our sample is cohortspecific and reflects the work-welfare experiences of women younger than most previous research. However, given that young women are less responsive to economic conditions, our estimates will understate the impact of labor market variables (Bound \& Holzer, 1995).

\section{Local Labor Market Variables: The QWI Database}

Our labor market information comes from the QWI, a previously unused database available online and maintained by the Census Bureau. ${ }^{16}$ The QWI is the culmination of the Bureau's efforts to merge administrative data on workers and business employment dynamics. Currently, 41 states and the District of Columbia participate in this data-sharing arrangement, and others have agreed to become partners. Such widespread participation is a strength of the QWI, enabling researchers to replicate analyses across a large number of states. These data provide unprecedented detail on local labor market dynamics. Among the distinctive features

\footnotetext{
${ }^{14}$ That demographic data are only available for the months during which sample members receive cash assistance can lead to sub-optimal strategies to ameliorate the problem. For example, in an analysis of reentries to welfare using California administrative data, Hoynes (2000) is forced to use values of demographic characteristics as of the end of the previous welfare spell.

${ }^{15}$ Specifically, women who received cash assistance between January 2002 and December 2005 have full demographic information available. Conversely, these data are unavailable for women who received cash assistance between January 1996 and December 2001 but not at any time between 2002 and 2005. As is the case for all studies using administrative data, predicting work and welfare receipt from a sample selected on the basis of current or future welfare receipt can result in biased estimates of the variables of interest. However, this characteristic of the data will lead us to understate the impact of labor market conditions.

${ }^{16}$ Data are available at http://lehd.did.census.gov/led/datatools/qwiapp.html. Detailed definitions of all variables are available at http://lehd.did.census.gov/led/library/techpapers/QWI_definitions.pdf.
} 
of the QWI are the availability of economic data on a quarterly basis, disaggregated to the county-level, and which allow researchers to organize information by SIC/NAICS code, gender, and age. Eight economic indicators are publicly available, but we focus on a sub-set of three gender and age-specific measures: new hires, new hires' earnings, and job flows. ${ }^{17}$ For comparison purposes, we also estimate models using the county unemployment rate. The QWI data are used to construct a county-by-quarter data file on new hires, new hires' earnings, and job flows in retail trade, accommodation/food services. ${ }^{18}$ We focus on these industries because, as previously stated, they are common destination jobs for individuals leaving welfare. Summary statistics for these measures are provided in Table 1.

The QWI measures of local labor market conditions are superior to the unemployment rate for a number of reasons. As others have noted, county-level unemployment rates are measured with substantial error, especially for small counties (Bartik, 1996; Hoynes, 2000). Furthermore, unemployment rates are blunt measures of economic conditions, since they do not provide information on the industry mix and generosity of wage offers within and across geographic areas. Unlike the QWI indicators, the unemployment rate is inadequate for describing labor market conditions among such narrowly defined sub-groups as single mothers. Finally, indicators of new hires and new hires' earnings are more accurate signals of labor market opportunities than total employment and earnings. These latter measures commingle information on new workers with a large number of individuals who have been with the same employer for substantial periods. Comparisons of new hires' earnings with

\footnotetext{
${ }^{17}$ The indicators are: total employment, earnings, new hires, new hires' earnings, net job flows, job creation/separation, and turnover. The Census Bureau defines these variables in the following manner. New hires: "A worker $i$ is defined as a new hire for employer $j$ in $t$ if $i$ has positive earnings at $j$ in $t$ but no earnings from $j$ in $t-1, t-2, t-3, t-4$." New hires earnings: "Sum of quarterly earnings at $j$ in $t$ for all $i$ who are full-quarter new hires, divided by the number of full-quarter new hires at $j$ in $t$, divided by three." Net job flows is "end-of-quarter employment in $t$ minus beginning-of-quarter employment in $t$." The primary data sources underlying the QWI indicators are UI wage records and employer reports for the Quarterly Census of Employment and Wages (QCEW) or ES-202 series.

See http://lehd.did.census.gov/led/library/techpapers/Brookings_QWI.pdf for a technical description of QWI variables.

${ }^{18}$ The two-digit NAICS code for these industries are as follows: retail trade, 44-45; accommodation and food services, 72.
} 
overall earnings in a given industry reveal that the latter are significantly higher than the former. Therefore, new hires' earnings are more precise indicators of what welfare leavers can expect when they receive a job offer.

Do these labor market measures vary sufficiently across counties and over time to identify their impact on employment and welfare use? One way to assess this is by regressing each economic indicator on a vector of fixed county and time effects and then calculating the $\mathrm{R}^{2}$. The greater the $\mathrm{R}^{2}$ after removing these factors, the less remaining variation there is in each measure to identify the effects on employment and welfare use. When this exercise is conducted on the county unemployment rate, the $\mathrm{R}^{2}$ is 0.87 , suggesting that 13 percent of the total variation in this measure remains after removing area and time effects. The $\mathrm{R}^{2}$ values for new hires in retail trade and accommodation/food services and new hires' earnings in both industries are, respectively, 0.86, 0.86, 0.50, and 0.61. It appears that labor market conditions vary sufficiently in Maryland, although the earnings measures contain significantly more variation than the employment measures. Employment levels reflect seasonal variation in labor demand, and so the time effects remove this systematic component.

\section{Empirical Model}

We estimate the effects of local labor market conditions on the full set of workwelfare choices faced by single mothers using a multinomial logit model. Whereas previous studies examine any work/welfare participation or likelihood of ending a welfare spell, our analysis captures two important, but largely ignored, alternatives for disadvantaged women: work without receiving welfare and neither work nor welfare. The number of single mothers working without welfare increased dramatically throughout the 1990s, and this outcome is increasingly the focus of states' welfare reform efforts. Unemployed mothers who are not receiving cash assistance are also a concern for policymakers because these women likely 
have several employment barriers - including low education, health problems and a history of domestic violence - and yet their financial needs are not being met by government aid (Blank, 2007). ${ }^{19}$

Stated formally, the probability that individual $i$, residing in county $c$, in time $t$ chooses the $j$ th work-welfare alternative is modeled in the following manner:

$$
\operatorname{Pr}\left(y=j \mid \mathbf{x}_{i c t}\right)=\frac{\exp \left(\alpha+\mathbf{Z}^{\prime}{ }_{i c} \beta\right)}{\sum_{j=1}^{J} \exp \left(\alpha+\mathbf{Z}^{\prime}{ }_{i c t} \beta\right)} .
$$

Four work-welfare combinations (j) are examined: (1) no work, no welfare; (2) no work, welfare; (3) work, welfare; and (4) work, no welfare. ${ }^{20}$ Estimates are interpreted in relation to category (1), women who are neither working nor receiving welfare. The $\mathbf{Z}^{\prime}$ is modeled in the following manner:

$$
\mathbf{Z}^{\prime}{ }_{i c t} \beta=\mathbf{X}_{i}^{\prime} \psi+\psi \mathrm{L}_{c t}+\psi \text { County }_{c}+\psi \text { Period }_{t}+\psi\left(\text { County }_{\mathrm{c}} \times \text { Trend }_{t}\right)
$$

where $\mathbf{X}^{\prime}$ is a vector of time invariant demographic controls including age, race, education, number of children, and the presence of additional children. As with most studies using administrative data, demographic characteristics are not observed when sample members are not receiving welfare. ${ }^{21}$ Therefore, we fix these variables as of the first quarter of welfare receipt. The L represents controls for labor market conditions across counties and quarters, specifically the unemployment rate, log of new hires, new hires' earnings $(/ 1,000)$, and gross

\footnotetext{
${ }^{19}$ It should be emphasized that women who are neither working nor receiving welfare comprise a non-trivial fraction of all mothers in our sample in any given quarter. This figure declines from about 40 to 20 percent during the first 12 months in the sample, and then remains in the neighborhood of 20 to 30 percent thereafter. That such a large number of single mothers are in this category is one of the key motivations to examine them in this paper.

${ }^{20}$ A concern with the use of multinomial logit models is the independence of irrelevant alternatives (IIA) assumption. Briefly, the IIA states that the odds of being observed in one of the alternatives does not depend on the presence or absence of other alternatives (i.e., the disturbances across the various categories are constrained to equal zero). This has implications for our dependent variable because two of the alternatives include welfare receipt and the other two include employment. However, results of Hausman tests indicate that we cannot reject the null hypothesis of independence across categories of the outcome variable.

${ }^{21}$ Given the limited number of demographic controls available in the administrative data, we considered including countylevel Census data in the models. However, these variables would also have to be fixed at a single point in time. In addition, many of these aggregate variables are highly correlated with each other, limiting their usefulness in the regressions. We decided in the end to rely on fixed effects to purge the model of individual unobserved heterogeneity.
} 
job flows $(/ 1,000){ }^{22}$ We also include county fixed effects and period effects in all models. ${ }^{23}$

County fixed effects control for unobserved area specific labor market shocks that influence work-welfare decisions, while period effects eliminate statewide year-to-year shocks. In other models, we incorporate county-specific time trends to account for unobserved factors that are trending within counties. Thus, labor market effects are identified using either within-county, year-to-year changes in economic conditions or using variation in the differential trends in economic opportunities across counties.

Although we include controls for unobserved heterogeneity, we are still concerned about endogeneity stemming from women's selective migration to areas based on labor market conditions. Endogenous migration is a well known form of unobserved heterogeneity in studies using low levels of geographic aggregation. Endogeneity will result, for example, if high-skilled women move to counties that implement strong work-based reforms in favorable economic conditions. On the other hand, it is plausible that women with weak work preferences and multiple employment barriers live in counties with unfavorable economic conditions. Both cases will result in biased estimates of the effects of labor market variables. $^{24}$ To deal with this issue, we create an indicator for whether women received a TANF grant through more than one county welfare office during the observation period.

\footnotetext{
${ }^{22}$ A possible objection to our parameterization of the labor market variables is that they are not adjusted for the fact that more populous counties will tend to have a comparatively large number of new hires in various industries (and so these measures should be scaled by the size of the labor force in each county). This strategy has several drawbacks, however. In particular, there are two key ways for this ratio to increase: (1) if both the numerator and denominator increase, but the numerator (new hires, for example) increases relatively more than the denominator; and (2) if the numerator remains fixed (or declines), and the denominator declines (or declines relatively more than the numerator). Scenario (2) is a concern because it indicates an improvement in economic conditions even though fewer people are being hired by the relevant industries. Given this concern and the common practice in the literature to avoid ratio measurements of labor market indicators [See Hoynes (2000) and Bartik \& Eberts (1999)], we decided to take the log of new hires and simply divide all earnings variables by 1,000 .

${ }^{23}$ Maryland contains 23 counties plus Baltimore City, which is considered a separate county in the Census Bureau nomenclature.

${ }^{24}$ Hoynes (2000) also points out the potential bias caused by selective migration and takes a number of steps to mitigate it. Specifically, the author examines the impact of economic conditions using women's county of residence as of the beginning of a welfare spell, rather than the contemporaneous county of residence. Results are not changed substantially when this correction is introduced. However, as she points out, women might have relocated prior to the beginning of a welfare spell, which would not have been picked up by Hoynes's correction. Hoynes also cites evidence by Long (1988) that inter-county migration rates are low among welfare recipients, who are significantly more likely to move within counties.
} 
Eligibility and benefit determination occur at the county level in Maryland, allowing us to construct fairly complete inter-county migration histories. ${ }^{25}$ In sensitivity analyses, we extend the basic model by adding a control for whether women received TANF through multiple local offices. Summary statistics for this variable suggest that movement between counties is a relatively rare event, and multiple moves are even rarer. Of the 1,712 women in our sample, 174 (10.1 percent) moved exactly one time between 1996 and 2005 and 111 (6.5 percent) moved multiple times. We also find mixed evidence on the relationship between mobility and several observable characteristics. Movers are more likely to be younger, white, and located in counties with lower unemployment rates, but are equally likely to be employed or receiving welfare.

\section{Estimation Results}

In this section, we present multinomial logit estimates of the impact of several local labor market indicators on the four work-welfare combinations defined above. To ease interpretations, we present marginal effects, evaluated at the mean of each variable. Results are organized in the following manner. For each labor market variable, we first show estimates based on models that do not include the time trends, followed by those that do. We begin with the unemployment rate (Table 2), since this is the most familiar measure, and then move on to new hires (Table 3), new hires' earnings (Table 4), and job flows (Table 5). Estimates for a number of sub-groups are presented in Table 6. Tables 3, 4, and 5 show results for retail trade and accommodation/food services combined and individually. ${ }^{26}$

\footnotetext{
${ }^{25}$ This approach is valid only to the extent that women receive at least two months of welfare, or have at least two welfare spells, because they must show up in the data as having received welfare at two different county welfare offices. However, very few women in the sample receive just one month of welfare. Another problem is that, while it controls for underlying preferences for welfare, we leave unobserved differential tastes for work that are correlated with economic conditions. This might not matter much either because tastes for welfare are likely to be highly (inversely) related to tastes for employment.

${ }^{26}$ We experimented with several adjustments to the standard errors, including Huber/White robust standard errors as well as corrections for the use of individual- and county-level data. Our results are not particularly sensitive to these corrections, and so we ultimately adjust for the grouped nature of the economic variables.
} 
Before turning to the main results, it is instructive to examine time series movements in a few categories of the outcome variable. Figure 1 presents quarterly work and welfare participation rates, typical measures in the literature, while Figure 2 displays the proportion of women simultaneously working and receiving welfare and those engaged in neither activity. It is immediately clear that the trajectories for any work or welfare use follow different paths from those defined by combinations of activities. Figure 2 reveals a dramatic decline in the number of women who are not working or receiving welfare during the first three years. At this point, women in the sample are 22-years-old. This decline is matched by large increases in the number of women working and receiving cash assistance. Both measures are relatively stable until the $28^{\text {th }}$ quarter, when a March-November 2001 national recession occurred. This led to a small, temporary decline in the number of women working and receiving welfare.

\section{Labor Market Conditions and Women's Work-Welfare Choices}

Looking first at Table 2, we find that the county unemployment rate is statistically significantly associated with women's work-welfare choices. The results for model (1), which omit linear time trends, suggest that increases in the unemployment rate raise the likelihood that women choose alternatives in which they receive welfare and decrease the likelihood of working, even in combination with welfare receipt. For example, a one point increase in the unemployment rate is associated with a 2.1 percentage point increase in the probability of not working and receiving welfare, but a three percentage point decrease in the probability of working without welfare. The effect of the unemployment rate on work and welfare receipt appears to be negative, but the coefficient is not statistically significant.

Model (2) adds county time trends to the specification. Generally speaking, this has the effect of substantially reducing the magnitude of the unemployment effect, while leaving the standard errors unchanged. For the no work/welfare category, the coefficient declines by 
43 percent; for the work/no welfare category, the coefficient declines by 55 percent. Interestingly, the magnitude of the unemployment coefficient in the work/welfare category increases and becomes statistically significant. These results are somewhat different from those reported in Hoynes (2000). We find that adding controls for unobserved heterogeneity does not impact the precision of our estimates (or at least reduce the size of the unemployment coefficient to render it statistically insignificant). Hoynes finds that adding period effects causes the unemployment rate to become insignificant, which remains so after adding time trends to the specification. ${ }^{27}$

Coefficients on the demographic variables in Table 2 take the expected sign and for the most part are statistically significant. Older women and those with at least a high school degree are more likely to work without receiving welfare. For example, the coefficient on educational attainment indicates that more highly educated women are about 14 percentage points more likely to be employed without receiving welfare. Conversely, women with more children in the assistance unit are less likely to work without welfare. Finally, the introduction of additional children into the assistance unit is associated with a decreased likelihood of working without welfare, with reductions of about 5.5 percentage points. Parameter estimates on the demographic variables do not change substantially when the linear time trends are added, so we suppress the presentation of these variables from all remaining tables.

Table 3 presents results substituting the $\log$ of new hires in retail trade and accommodation/food services for the unemployment rate. For comparison purposes,

\footnotetext{
${ }^{27}$ Although Hoynes (2000) examines different outcomes (welfare exit and reentry propensities), the different results are still intriguing. She attributes the disappearing unemployment effect to either measurement error in calculating local area employment statistics or the lack of cross-county variation in the measure. It is likely that measurement error is the key factor. During the years covered by Hoynes's analysis - 1987 to 1992 - county-level unemployment rates are known to be measured with substantial error, especially in less populous counties. Over time, however, these unemployment rates are measured more precisely, which may explain why our estimates remain statistically significant after introducing all controls for unobserved heterogeneity.
} 
estimates are shown for models with and without county time trends. Model (1) suggests that combined new hires in both industries are strongly related to all work-welfare combinations. Specifically, an increase in new hires decreases the likelihood of choosing alternatives in which work is not one of the activities and increases the likelihood of choosing any work alternative. Interestingly, the magnitude of the positive effect is 32 percent greater for women working without welfare, relative to those working and receiving welfare. Such a finding indicates that young women are responsive to the level of hiring in key industries, and that a period of healthy employment growth provides a powerful incentive to rely on work alone. Models (2) and (3) examine individual measures of new hires in retail and accommodation/food services, and it appears that the results in model (1) are driven by the strong estimates for accommodation/food services. The coefficient is statistically significant across all work-welfare states, whereas just the coefficient in the work/no welfare category is significant for retail trade. This pattern is not surprising given that nearly one-fourth of Maryland employed welfare leavers work in the service sector in the first quarter after exiting. Finally, a close inspection of the models with and without controls for county time trends indicates that adding trends generally strengthens the results by generating coefficients with the expected sign.

Table 4 presents estimates of new hires' earnings in retail trade and accommodation/food services. Generally speaking, these results are less sensitive to the inclusion of county time trends. A plausible explanation is that employment carries a much stronger seasonal component (e.g., temporary holiday employment) than the determinants of earnings. However, most coefficients experience fairly steep declines when the trend variables are included. Notably, the magnitude of the earnings coefficients in the work/no welfare alternative experience a sharp decline, suggesting that earnings and 
employment/welfare receipt are trending together. Nevertheless, combined new hires' earnings are strongly related to women's decisions in all categories, and once again, increased earnings are positively associated with alternatives that include employment. A $\$ 1,000$ increase in quarterly new hires earnings is associated with a 6.6 percentage point increase (3.4 +3.2 ) in the probability of choosing either work state. Unlike the case of employment, the magnitude of the effect of combined earnings is similar across the work/welfare and work/no welfare alternatives. Another interesting difference between the employment and earnings results is that retail earnings are related to all work-welfare combinations. Thus, it appears that the returns to work in key industries provide important incentives to choose any work alternative, even if women are working in conjunction with receiving cash assistance.

Estimates for the final measure of labor market conditions, job flows, are presented in Table 5. Capturing the effects of job flows is complicated by the fact that the measure varies substantially across counties but also takes on negative values, which precludes us from expressing the measure in logarithmic form. None of the coefficients associated with combined job flows is statistically significant, and the magnitude of the coefficients implies economically small effects. When models are estimated separately for retail trade and accommodation/food services, most of the coefficients become significant, although some have unexpected signs, as long as county time trends are omitted. Including trends renders most of the estimates insignificant, suggesting that a large component of job flows is trending with unobserved factors associated with the work-welfare alternatives.

\section{The Economic Impact of Labor Market Conditions}

We assess the relative importance of labor market conditions by simulating the effects of changes in the unemployment rate, new hires, and new hires' earnings on the likelihood of choosing each work-welfare alternative. Specifically, we hold all variables at their mean 
values and calculate the percent change in the probability that women are observed in each category as the unemployment rate declines from 7.0 to 5.0 percent, new hires increase 30 percent, and new hires' earnings increase 20 percent. $^{28}$ Changes of this magnitude are common for Maryland over the 10-year study period, and represent reasonable shifts during periods of economic expansion and contraction. The simulations are based on models estimated in Tables 2, 3, and 4 and include all controls for unobserved heterogeneity. For comparison purposes, we simulate the effects of changes in educational attainment, an important supply-side determinant of work and welfare receipt. Results from this exercise are presented in Table 6 .

Generally speaking, the simulations reveal fairly consistent economic impacts across all three labor market measures. Decreases in the unemployment rate and increases in new hires and new hires' earnings increase the likelihood that single mothers choose alternatives that include work, irrespective of whether individuals also receive welfare. However, labor market improvements appear to have stronger effects on employment that coincides with welfare receipt. For example, as the unemployment rate declines from 7.0 to 5.0 percent, there is an eight percent increase in the probability of moving into work while receiving welfare, and a 6.7 percent increase in the probability of working without welfare. These differences are more pronounced for both employment-based measures. An increase of 30 percent in the number of new hires in retail trade and accommodation/food services leads to a 10.3 percent increase in the fraction of women working and receiving welfare, but only a 3.6 percent increase in employment alone. The corresponding figures for new hires' earnings are, respectively, 7.7 percent and 1.9 percent. Overall, these results indicate that labor market

\footnotetext{
${ }^{28}$ Baseline simulation results for new hires and new hires' earnings are derived from both variables set to their mean values. These simulations are conducted on the combined measures for retail trade and accommodation/food services.
} 
improvements provide strong work incentives, but most of this employment effect is concentrated among women who continue receiving cash assistance.

One way to assess the relative importance of labor market conditions is by comparing the above simulation results with factors that can reasonably be targeted by policy interventions. We focus on increases in educational attainment, a commonly cited human capital determinant of economic independence. In particular, we simulate the impact of providing all single mothers with at least a high school education, compared to a baseline in which no mother has such a degree. As shown in Table 6, this policy experiment results in comparatively large effects on work-welfare decisions that are concentrated among women who are working without welfare. One should bear in mind, however, that this simulation is based on a large change in human capital accumulation, and that simulations based on increasing education from the sample mean (60 percent) yield smaller employment effects.

\section{Extensions and Tests of Robustness}

To assess the robustness of the main results, we undertake a number of sensitivity analyses. We provide only a sub-set of results and a brief discussion here, but full results from these tests are available upon request. To this point, we have estimated the average impact of local labor market conditions. There are good reasons to believe, however, that such factors have heterogeneous effects depending on the observable characteristics of women (Hoynes, 2000). Table 7 presents results for a number of key demographic subgroups, including African American women and those with less than a high school degree. To conserve space, we conduct the analyses on combined new hires and new hires' earnings in retail trade and accommodation/food services.

Comparing the estimates for African American and white women, it is difficult to detect a clear pattern in the results. Increases in new hires and new hires' earnings generate 
larger effects for African American women at the no work/welfare and work/welfare alternatives, but white women appear to be more responsive at the work/no welfare alternative. Thus, it appears that improved labor market opportunities offer a strong incentive for African American women to work in conjunction with welfare receipt. White women, on the other hand, respond to labor market improvements in a way that encourages them to rely on work alone for financial well-being. A possible explanation for these differential effects is that some groups of women have greater skills and fewer work barriers that allow them to take full advantage of economic expansions.

Turning to the models for educational attainment, we find similar patterns. High school drop-outs are more responsive to labor market opportunities at the no work/welfare and work/welfare alternatives, while those who completed high school are more responsive at the work/no welfare alternative. These differential effects are more pronounced than the race effects. In addition, the results appear to corroborate the skills argument made above. While a favorable economic environment is a strong incentive for low-skilled women to combine work with welfare, it cannot by itself encourage such women to move entirely off welfare and into work. Higher-skilled women operating in favorable conditions are in a better position to take advantage of labor market opportunities, and thus are more responsive to such opportunities as they move into employment without continuing on the welfare rolls.

We also examine the impact of labor market conditions on the traditional dichotomous work and welfare decisions. All employment variables (i.e., unemployment rate, combined new hires, combined new hires' earnings, and job flows) are strongly associated with employment, but only the unemployment rate is statistically significant in the welfare use model. However, the absolute value of the unemployment coefficient declines dramatically, from -1.7 in the employment model to 0.8 in the welfare model. Such results imply that 
individuals are more sensitive to labor market opportunities when deciding to engage in any work, even if employment coincides with welfare use. Hoynes (2000) finds similar results: economic conditions are consistently related to welfare exits but largely unrelated to reentry.

One final robustness check is conducted. We estimate multinomial logit models that control for whether women received cash assistance through multiple county welfare offices during the 10-year observation period. As previously stated, this variable captures unobserved preferences for work and welfare that may lead women to migrate to areas based on labor market conditions. The coefficient on the "mover" variable is never statistically significant, indicating that conditional on controls for observable characteristics and fixed effects, women who moved sometime during the observation period are equally likely to be located in any of the work-welfare states. Moreover, estimates on the economic variables are unchanged. Interestingly, the estimate for "movers" remains statistically insignificant even after removing controls for unobserved heterogeneity. As a final check, we estimate the basic model only on women who did not move during the 10 -year observation period. These results show little change in the estimated effects of labor market conditions. The robustness of our main findings to this extension is not surprising, given that few women migrated during the sampling period and that we control for many of the characteristics correlated with relocation decisions.

\section{Conclusion}

Merging administrative data for the state of Maryland with gender- and age-specific labor market information, this paper estimates the impact of economic conditions on the full set of work-welfare alternatives. In doing so, we make a number of contributions to the literature. We introduce the QWI database as a potentially rich resource for county-level economic indicators. Although these measures have not been used in previous studies, their 
widespread availability creates promising opportunities for researchers wishing to replicate and compare results across states. New hires and new hires' earnings, in particular, are superior to measures of overall employment and earnings because they accurately reflect what recent welfare leavers are likely to encounter during their job search. Moreover, the QWI database allows users to filter economic measures by gender, age-group, industry, and region. Our administrative data also have a number of desirable qualities: large sample size, accuracy in employment and welfare reporting, and access to quarterly observations over a 10 -year period.

Our results suggest that women respond to local labor market opportunities in ways predicted by standard economic models. As the unemployment rate declines and new hires and earnings in key industries increase, women are expected to choose alternatives that include work, even if it coincides with welfare receipt. Improved economic conditions decrease the incentive to remain out of work and on welfare. These findings hold for local employment and earnings opportunities in the retail and accommodation/food services industries, as well as for the unemployment rate. Our findings also suggest that African American women and high school drop-outs respond differently to labor market conditions than white women and those with at least a high school degree. Specifically, the former groups tend to be more responsive to economic improvements when they are allowed to work in conjunction with welfare receipt. Economic opportunities provide more powerful incentives for the latter groups as they move into employment without welfare receipt. Finally, our results are robust to controls for unobserved heterogeneity and endogeneous relocation choices.

Two important questions are raised by this paper. First, can our results shed light on why previous studies have not consistently found significant relationships between economic 
conditions and work-welfare decisions? Second, to what extent can labor market opportunities, by themselves, fulfill the goal of recent welfare reforms? As to the first question, our results suggest that county- as opposed to state-level labor market data are crucial for precisely estimating labor market effects. Disaggregating labor market measures by gender, age-group, and relevant industries is also preferable to overall measures of the unemployment rate, employment, and earnings. Still another factor is the availability of multiple observations per year, so that short-term employment shocks are accounted for and short employment/welfare spells are identified. While reducing the magnitude of estimated effects, in most cases the inclusion of fixed effects and time trends does not qualitatively alter results from simpler models. Thus, unobserved heterogeneity is important but not determinative.

As to the second question, it is important to stress that in an era of work-based social policy, strong economic growth is increasingly relied upon to move former welfare recipients toward economic independence. Our results suggest, however, that economic growth is not a panacea. Favorable labor market conditions alone cannot reliably move welfare recipients into employment. For many women, improved labor market opportunities provide strong incentives to combine work with welfare. For fewer women are these incentives strong enough to rely on work alone for financial well-being. In addition, the presence of heterogeneous labor market effects complicates our understanding of who is most likely to benefit from favorable economic conditions, or which characteristics public policy can reasonably alter so that women are in a position to take full advantage of economic expansions.

Our findings have important policy implications. Several provisions of states' welfare reforms rely extensively on the ability of local labor markets to absorb welfare recipients and 
provide them with incentives to offset participation in cash assistance programs. The increased use of mandatory job search programs and formal cash diversion grants are evidence of this reliance. A mixed regime of policy "carrots" and "sticks" that places equal emphasis on strong work mandates when economic conditions are favorable and softening those mandates when conditions are less favorable is necessary in an environment that stresses a "work first" philosophy. One way to achieve this balance is for national policymakers and state welfare administrators to shift focus from state-level assessments of economic conditions to one that emphasizes local employment opportunities. Anecdotal evidence from Maryland suggests that county administrators adjust to economic fluctuations in an ad hoc manner. An explicit policy shift that provides local offices with additional flexibility would allow caseworkers to systematically tailor TANF reforms to the economic environment in which welfare recipients operate. 


\section{References}

Bane, M. \& Ellwood, D. (1983). The dynamics of dependence: The routes to selfsufficiency. Office of the Assistant Secretary for Planning and Evluation, U.S. Department of Health and Human Services.

Bartik, T. (1996). The distributional effects of local labor demand and industrial mix: estimates using individual panel data. Journal of Urban Economics, 40, 150-178.

Bartik, T. \& Eberts, R. (1999). Examining the effect of industry trends and structure on welfare caseloads. In S. H. Danziger (ed.) Economic Conditions and Welfare Reform. Kalamazoo, MI: W.E. Upjohn Institute for Employment Research.

Becker, G. (1973). A theory of marriage: Part I. Journal of Political Economy, 81, 813-846.

Becker, G. (1981). A Treatise on the Family. Cambridge, MA: Harvard University Press.

Blank, R. (1989). Analyzing the length of welfare spells. Journal of Public Economics, 39, $245-273$

Blank, R. (2001). What causes public assistance caseloads to grow? Journal of Human Resources, 36, 85-118.

Blank, R. (2002). Evaluating welfare reform in the United States. Journal of Economic Literature, 40, 1105-66.

Blank, R. (2007). Improving the safety net for single mothers who face serious barriers to work. The Future of Children, 17, 183-197.

Blank, R. \& Ruggles, P. (1996). When do women use AFDC and food stamps: The dynamics of eligibility versus participation. Journal of Human Resources, 31, 57-89.

Blau, F., Kahn, L., \& Waldfogel, J. (2000). Understanding young women's marriage decisions: The role of labor and marriage market conditions. Industrial and Labor Relations Review, 53, 624-647.

Bound, J. \& Holzer, H. (1995). Structural changes, employment outcomes, and population adjustments among whites and blacks: 1980-1990. Discussion Paper: Institute for Research on Poverty.

Council of Economic Advisors (CEA) (1997). Explaining the Decline in Welfare Receipt, 1993-1996. Washington, D.C. May.

Council of Economic Advisors (CEA) (1999). The Effects of Welfare Policy and the Economic Expansions on Welfare Caseloads: An Update. Washington, D.C. August. 
Fang, H. \& Keane, M. (2004). Assessing the impact of welfare reform on single mothers. Brookings Papers on Economic Activity, 2004, 1-116.

Figlio, D. \& Ziliak, J. (1999). Welfare reform, the business cycle, and the decline in AFDC caseloads. In S. H. Danziger (ed.) Economic Conditions and Welfare Reform. Kalamazoo, MI: W.E. Upjohn Institute for Employment Research.

Fitzgerald, J. (1991). Welfare durations and the marriage market: Evidence from the Survey of Income and Program Participation. Journal of Human Resources, 26, 545-561.

Fitzgerald, J. (1995). Local labor markets and local area effects on welfare duration. Journal of Policy Analysis and Management, 14, 43-67.

Grogger, J. (2003). The effects of time limits, the EITC, and other policy changes on welfare use, work, and income among female-headed families. Review of Economics and Statistics, 85, 394-408.

Grogger, J. (2004a). Time limits and welfare use. Journal of Human Resources, 39, 405424.

Grogger, J. (2004b). Welfare transitions in the 1990s: The economy, welfare policy, and the EITC. Journal of Policy Analysis and Management, 23, 671-698.

Grogger, J. \& Karoly, L. (2005). Welfare Reform: Effects of A Decade of Change. Cambridge, MA: Harvard University Press.

Harris, K. (1993). Work and welfare use among single women in poverty. American Journal of Sociology, 99, 317-352.

Harris, K. (1996). Life after welfare: Women, work, and repeat dependency. American Sociological Review, 61, 407-426.

Herbst, C. (2007). Codependent or independent? Heterogeneous effects of social policy reforms across labor market conditions. Unpublished Doctoral Dissertation: University of Maryland School of Public Policy.

Hofferth, S., Stanhope, S., \& Harris, K. (2002). Exiting welfare in the 1990s: Did public policy influence recipients' behavior? Population Research and Policy Review, 21, 433-72.

Hofferth, S., Stanhope, S., \& Harris, K. (2005). Remaining off welfare in the 1990s: The influence of public policy and economic conditions. Social Science Research, 34, 426-453.

Hoynes, H. (2000). Local labor market and welfare spells: Do demand conditions matter? Review of Economics and Statistics, 82, 351-368. 
Hoynes, H. \& MaCurdy, T. (1994). Has the decline in benefits shortened welfare spells? American Economic Review, 84, 43-48.

Klerman, J. \& Haider, S. (2004). A stock-flow analysis of the welfare caseload. Journal of Human Resources, 39, 865-886.

Klerman, J., Ringel, J., \& Roth, B. (2005). Under-reporting of Medicaid and welfare in the Current Population Survey. RAND Corporation Working Paper WR-169-3.

Levine, P. \& Whitmore, D. (1998). The impact of welfare reform on the AFDC caseload. National Tax Association Proceedings-1997, 24-33.

Looney, A. (2005). The effects of welfare reform and related policies on single mothers' welfare use and employment in the 1990s. Working Paper 2005-45. Finance and Economics Discussion Series. Washington DC: Federal Reserve Board.

Long, L. (1988). Migration and Residential Mobility in the United States. New York, NY: The Russell Sage Foundation.

Lopoo, L. \& DeLeire, T. (2006). Did welfare reform influence the fertility of young teens? Journal of Policy Analysis and Management, 25, 275-298.

Meyer, B. \& Rosenbaum, D. (2001). Welfare, the earned income tax credit, and the labor supply of single mothers. Quarterly Journal of Economics, 116, 1063-1114.

Moffitt, R. (1999). The effect of pre-PRWORA waivers on AFDC caseloads and female earnings, income, and labor force behavior. In S. H. Danziger (ed.) Economic Conditions and Welfare Reform. Kalamazoo, MI: W.E. Upjohn Institute for Employment Research.

Mueser, P., Stevens, D., \& Troske, K. (2007). The impact of welfare reform on leaver characteristics, employment and recidivism: An analysis of Maryland and Missouri. IZA Discussion Paper No. 3131.

Noonan, M., Smith, S., \& Corcoran, M. (2005). Examining the impact of welfare reform, labor market conditions, and the Earned Income Tax Credit on the employment of black and white single mothers. Working Paper No. 123-05. Institute of Industrial Relations: University of California, Berkeley.

O'Neil, J. \& Hill, A. (2001). Gaining Ground? Measuring the Impact of Welfare Reform on Welfare and Work. Civic Report No. 17. New York, NY: Manhattan Institute for Policy Research.

Pavetti, LaDonna. (1993). The dynamics of welfare and work: exploring the process by which women work their way off welfare. Unpublished Doctoral Dissertation: Harvard University. 
Schiller, B. (1999). State welfare-reform impacts: Content and enforcement effects. Contemporary Economic Policy, 17, 210-222.

Schoeni, R. \& Blank, R. (2000). What has welfare reform accomplished? Impacts on welfare participation, employment, income, poverty, and family structure. Working Paper No. 7627. Cambridge, MA: National Bureau of Economic Research.

Taeuber, C., Resnick, D., Love, S., Staveley, J., Wilde, P., \& Larson, R. (2004). Differences in Estimates of Food Stamp Program Participation Between Surveys and Administrative Data, U.S. Department of Commerce, Bureau of the Census.

U.S. Department of Health and Human Services, Administration for Children and Families, Office of Family Assistance (DHHS) (2006). Characteristics and Financial Circumstances of TANF Recipients. Available at: http://www.acf.hhs.gov/programs/ofa/tanfindex.htm. Washington, DC: U.S. Department of Health and Human Services.

Wallace, G. \& Blank, R. (1999). What goes up must come down? In S. H. Danziger (ed.) Economic Conditions and Welfare Reform. Kalamazoo, MI: W.E. Upjohn Institute for Employment Research.

Ziliak, J., Figlio, D., Davis, E., \& Connolly, L. (2000). Accounting for the decline in AFDC caseloads: Welfare reform or the economy? Journal of Human Resources, 35, 570586. 
Table 1: Summary Statistics for the Analysis Sample

\begin{tabular}{|c|c|c|c|c|}
\hline $\begin{array}{c}\text { Variable } \\
\end{array}$ & Mean & $\begin{array}{l}\text { Standard } \\
\text { Deviation }\end{array}$ & Minimum & Maximum \\
\hline Demographic Variables & & & & \\
\hline $\begin{array}{l}\text { Age at first quarter of welfare receipt } \\
\begin{array}{l}18-19 \\
20-22 \\
23-25 \\
26-28\end{array}\end{array}$ & $\begin{array}{l}0.522 \\
0.176 \\
0.179 \\
0.121\end{array}$ & $\begin{array}{l}0.499 \\
0.381 \\
0.383 \\
0.326\end{array}$ & $\begin{array}{l}0 \\
0 \\
0 \\
0\end{array}$ & $\begin{array}{l}1 \\
1 \\
1 \\
1\end{array}$ \\
\hline Black & 0.767 & 0.422 & 0 & 1 \\
\hline White & 0.211 & 0.408 & 0 & 1 \\
\hline Other/missing race or ethnicity & 0.021 & 0.143 & 0 & 1 \\
\hline At least high school degree & 0.580 & 0.493 & 0 & 1 \\
\hline Missing information on education & 0.042 & 0.200 & 0 & 1 \\
\hline $\begin{array}{l}\text { Number of children at first quarter of } \\
\text { welfare receipt } \\
0 \\
1 \\
2 \\
3+\end{array}$ & $\begin{array}{l}0.130 \\
0.665 \\
0.138 \\
0.033\end{array}$ & $\begin{array}{l}0.337 \\
0.471 \\
0.345 \\
0.180\end{array}$ & $\begin{array}{l}0 \\
0 \\
0 \\
0\end{array}$ & $\begin{array}{l}1 \\
1 \\
1 \\
1\end{array}$ \\
\hline $\begin{array}{l}\text { Additional children after first quarter of } \\
\text { welfare receipt }\end{array}$ & 0.573 & 0.494 & 0 & 1 \\
\hline Missing information on children & 0.031 & 0.174 & 0 & 1 \\
\hline Labor Market Variables & & & & \\
\hline County unemployment rate, quarterly & 6.15 & 1.97 & 1.60 & 18.6 \\
\hline $\begin{array}{l}\text { New hires, quarterly, } 1000 \text { s } \\
\text { Retail trade } \\
\text { Accommodation/food services }\end{array}$ & $\begin{array}{l}6.823 \\
6.837\end{array}$ & $\begin{array}{l}3.907 \\
2.980\end{array}$ & $\begin{array}{l}0.054 \\
0.043\end{array}$ & $\begin{array}{l}20.552 \\
14.817\end{array}$ \\
\hline $\begin{array}{l}\text { New hires earnings, quarterly, 1000s } \\
\text { Retail trade } \\
\text { Accommodation/food services }\end{array}$ & $\begin{array}{l}1.402 \\
0.991\end{array}$ & $\begin{array}{l}0.211 \\
0.204\end{array}$ & $\begin{array}{l}0.654 \\
0.293\end{array}$ & $\begin{array}{l}3.259 \\
3.426\end{array}$ \\
\hline $\begin{array}{l}\text { Job flows, quarterly, 1000s } \\
\text { Retail trade } \\
\text { Accommodation/food services }\end{array}$ & $\begin{array}{l}0.213 \\
0.206\end{array}$ & $\begin{array}{l}1.330 \\
1.325\end{array}$ & $\begin{array}{l}-5.165 \\
-6.425\end{array}$ & $\begin{array}{l}8.471 \\
7.834\end{array}$ \\
\hline $\begin{array}{l}\text { Number of individuals } \\
\text { Number of person-quarter combinations }\end{array}$ & \multicolumn{4}{|c|}{$\begin{array}{c}1,712 \\
68,480\end{array}$} \\
\hline
\end{tabular}


Table 2: Multinomial Logit Estimates of Work-Welfare Combinations:

County Unemployment Rate, All Women

\begin{tabular}{|c|c|c|c|c|c|c|}
\hline Variable & \multicolumn{2}{|c|}{$\begin{array}{l}\text { No Work, } \\
\text { Welfare }\end{array}$} & \multicolumn{2}{|c|}{$\begin{array}{l}\text { Work, } \\
\text { Welfare }\end{array}$} & \multicolumn{2}{|c|}{$\begin{array}{c}\text { Work, } \\
\text { No Welfare }\end{array}$} \\
\hline $\begin{array}{l}\text { (1): Omit county- } \\
\text { specific time } \\
\text { trends }\end{array}$ & $\begin{array}{c}\text { Marginal } \\
\text { Effect }\end{array}$ & $\begin{array}{c}\text { Standard } \\
\text { Error }\end{array}$ & $\begin{array}{c}\text { Marginal } \\
\text { Effect }\end{array}$ & $\begin{array}{c}\text { Standard } \\
\text { Error }\end{array}$ & $\begin{array}{c}\text { Marginal } \\
\text { Effect }\end{array}$ & $\begin{array}{c}\text { Standard } \\
\text { Error }\end{array}$ \\
\hline Unemployment rate & 0.021 & $(0.003)^{* * *}$ & -0.002 & $(0.002)$ & -0.029 & $(0.004)^{* * *}$ \\
\hline Age $20-22$ & -0.055 & $(0.009) * * *$ & -0.033 & $(0.005) * * *$ & 0.001 & $(0.016)$ \\
\hline Age $23-25$ & -0.132 & $(0.008) * * *$ & -0.083 & $(0.004) * * *$ & 0.086 & $(0.018) * * *$ \\
\hline Age 26-28 & -0.175 & $(0.007) * * *$ & -0.107 & $(0.003) * * *$ & 0.124 & $(0.024) * * *$ \\
\hline Black & 0.017 & $(0.010) *$ & 0.057 & $(0.005) * * *$ & -0.008 & $(0.016)$ \\
\hline Other/missing race & 0.048 & $(0.036)$ & 0.033 & $(0.021)$ & -0.058 & $(0.041)$ \\
\hline $\begin{array}{l}\text { At least high school } \\
\text { degree }\end{array}$ & -0.074 & $(0.008)^{* * *}$ & -0.004 & $(0.004)$ & 0.135 & $(0.012) * * *$ \\
\hline Missing education & -0.097 & $(0.014) * * *$ & -0.043 & $(0.007) * * *$ & 0.141 & $(0.031) * * *$ \\
\hline 1 child & -0.001 & $(0.010)$ & 0.015 & $(0.006)^{* *}$ & -0.0007 & $(0.017)$ \\
\hline 2 children & 0.020 & $(0.015)$ & 0.012 & $(0.009)$ & -0.041 & $(0.022) *$ \\
\hline $3+$ children & 0.035 & (0.033) & 0.006 & $(0.016)$ & -0.087 & $(0.035) * *$ \\
\hline Additional children & 0.072 & $(0.008) * * *$ & 0.012 & $(0.005) * *$ & -0.056 & $(0.013) * * *$ \\
\hline Missing children & -0.074 & $(0.024) * * *$ & -0.020 & $(0.015)$ & 0.062 & $(0.040)$ \\
\hline Constant & -0.287 & $(0.044) * * *$ & -0.080 & (0.078) & 0.246 & $(0.094) * * *$ \\
\hline County fixed effects & & & & es & & \\
\hline Period effects & & & & es & & \\
\hline County-specific time & & & & & & \\
\hline $\begin{array}{l}\text { trenas } \\
\text { Number of }\end{array}$ & & & & & & \\
\hline observations & & & & & & \\
\hline Log-likelihood & & & -82 & 9.233 & & \\
\hline $\begin{array}{l}\text { (2): I nclude } \\
\text { county-specific } \\
\text { time trends }\end{array}$ & $\begin{array}{c}\text { Marginal } \\
\text { Effect }\end{array}$ & $\begin{array}{l}\text { Standard } \\
\text { Error }\end{array}$ & $\begin{array}{l}\text { Marginal } \\
\text { Effect }\end{array}$ & $\begin{array}{l}\text { Standard } \\
\text { Error }\end{array}$ & $\begin{array}{c}\text { Marginal } \\
\text { Effect }\end{array}$ & $\begin{array}{l}\text { Standard } \\
\text { Error }\end{array}$ \\
\hline Unemployment rate & 0.012 & $(0.003)^{* * *}$ & -0.004 & $(0.002)^{*}$ & -0.013 & $(0.003) * * *$ \\
\hline Age $20-22$ & -0.055 & $(0.009)^{* * *}$ & -0.033 & $(0.005) * * *$ & 0.001 & $(0.016)$ \\
\hline Age $23-25$ & -0.133 & $(0.008) * * *$ & -0.083 & $(0.004) * * *$ & 0.086 & $(0.018) * * *$ \\
\hline Age 26-28 & -0.175 & $(0.007) * * *$ & -0.107 & $(0.003) * * *$ & 0.124 & $(0.024) * * *$ \\
\hline Black & 0.018 & $(0.010)^{*}$ & 0.057 & $(0.005) * * *$ & -0.008 & $(0.016)$ \\
\hline Other/missing race & 0.049 & $(0.036)$ & 0.033 & $(0.021)$ & -0.058 & $(0.042)$ \\
\hline At least high school & -0.074 & $(0.008) * * *$ & -0.004 & (0.004) & 0.136 & $(0.012) * * *$ \\
\hline degree & & & & & & \\
\hline Missing education & -0.097 & $(0.014)^{* * *}$ & -0.042 & $(0.007) * * *$ & 0.141 & $(0.031)^{* * *}$ \\
\hline 1 child & -0.001 & $(0.010)$ & 0.015 & $(0.006) * *$ & -0.0006 & $(0.017)$ \\
\hline 2 children & 0.020 & $(0.015)$ & 0.012 & $(0.009)$ & -0.041 & $(0.022) *$ \\
\hline $3+$ children & 0.035 & (0.033) & 0.005 & $(0.016)$ & -0.087 & $(0.036)^{* *}$ \\
\hline Additional children & 0.073 & $(0.008) * * *$ & 0.013 & $(0.005)^{* *}$ & -0.056 & $(0.013) * * *$ \\
\hline Missing children & -0.074 & $(0.024)^{* * *}$ & -0.019 & $(0.015)$ & 0.062 & $(0.041)$ \\
\hline Constant & -0.767 & $(0.151)^{* * *}$ & -0.266 & $(0.086)^{* * *}$ & 0.470 & $(0.167) * * *$ \\
\hline County fixed effects & & & & es & & \\
\hline Period effects & & & & es & & \\
\hline County-specific time & & & & es & & \\
\hline
\end{tabular}




\section{trends}

Number of

68,480

observations

Log-likelihood

\section{$-82,516.419$}

Notes: Marginal effects are presented, along with standard errors (in parentheses). Standard errors are adjusted for the grouping of local labor market variables. The dependent variable is defined as follows: $1=$ no work, no welfare; $2=$ no work, welfare; $3=$ work, welfare; $4=$ work, no welfare. The base category in all models is $1 . * * *, * * *$ indicate statistical significance at the $1 \%, 5 \%$, and $10 \%$ levels, respectively.

Table 3: Multinomial Logit Estimates of Work-Welfare Combinations: Quarterly New Hires in Various Industries, All Women

\begin{tabular}{|c|c|c|c|c|c|c|c|}
\hline Variable & & \multicolumn{2}{|c|}{$\begin{array}{c}\text { No Work, } \\
\text { Welfare }\end{array}$} & \multicolumn{2}{|c|}{$\begin{array}{l}\text { Work, } \\
\text { Welfare }\end{array}$} & \multicolumn{2}{|c|}{$\begin{array}{c}\text { Work, } \\
\text { No Welfare }\end{array}$} \\
\hline $\begin{array}{l}\text { (1): Combined retail } \\
\text { trade and } \\
\text { accommodation/ food } \\
\text { services }\end{array}$ & $\begin{array}{l}\text { County } \\
\text { time } \\
\text { trends }\end{array}$ & $\begin{array}{c}\text { Marginal } \\
\text { Effect }\end{array}$ & $\begin{array}{l}\text { Standard } \\
\text { Error }\end{array}$ & $\begin{array}{l}\text { Marginal } \\
\text { Effect }\end{array}$ & $\begin{array}{l}\text { Standard } \\
\text { Error }\end{array}$ & $\begin{array}{c}\text { Marginal } \\
\text { Effect }\end{array}$ & $\begin{array}{l}\text { Standard } \\
\text { Error }\end{array}$ \\
\hline In(combined new hires) & $\begin{array}{l}\text { No } \\
\text { Yes }\end{array}$ & $\begin{array}{l}-0.007 \\
-0.041\end{array}$ & $\begin{array}{l}(0.012) \\
(0.010) * * *\end{array}$ & $\begin{array}{l}0.070 \\
0.044\end{array}$ & $\begin{array}{l}(0.009) * * * \\
(0.010) * * *\end{array}$ & $\begin{array}{c}-0.003 \\
0.058\end{array}$ & $\begin{array}{l}(0.013) \\
(0.012) * * *\end{array}$ \\
\hline $\begin{array}{l}\text { County fixed effects } \\
\text { Period effects } \\
\text { Number of observations }\end{array}$ & & & & & $\begin{array}{l}\text { es } \\
\text { es } \\
480\end{array}$ & & \\
\hline (2): Retail trade & & $\begin{array}{l}\text { Marginal } \\
\text { Effect }\end{array}$ & $\begin{array}{l}\text { Standard } \\
\text { Error }\end{array}$ & $\begin{array}{l}\text { Marginal } \\
\text { Effect }\end{array}$ & $\begin{array}{l}\text { Standard } \\
\text { Error }\end{array}$ & $\begin{array}{l}\text { Marginal } \\
\text { Effect }\end{array}$ & $\begin{array}{l}\text { Standard } \\
\text { Error }\end{array}$ \\
\hline In(new hires) & $\begin{array}{l}\text { No } \\
\text { Yes }\end{array}$ & $\begin{array}{c}0.009 \\
-0.023\end{array}$ & $\begin{array}{l}(0.011) \\
(0.015)\end{array}$ & $\begin{array}{l}0.050 \\
0.018\end{array}$ & $\begin{array}{l}(0.008)^{* * * *} \\
(0.013)\end{array}$ & $\begin{array}{c}-0.029 \\
0.035\end{array}$ & $\begin{array}{l}(0.013) * * \\
(0.016) * *\end{array}$ \\
\hline $\begin{array}{l}\text { County fixed effects } \\
\text { Period effects } \\
\text { Number of observations }\end{array}$ & & & & & $\begin{array}{l}\text { es } \\
\text { es } \\
480\end{array}$ & & \\
\hline $\begin{array}{l}\text { (3): Accommodation } \\
\text { and food services }\end{array}$ & & $\begin{array}{l}\text { Marginal } \\
\text { Effect }\end{array}$ & $\begin{array}{l}\text { Standard } \\
\text { Error }\end{array}$ & $\begin{array}{l}\text { Marginal } \\
\text { Effect }\end{array}$ & $\begin{array}{l}\text { Standard } \\
\text { Error }\end{array}$ & $\begin{array}{l}\text { Marginal } \\
\text { Effect }\end{array}$ & $\begin{array}{l}\text { Standard } \\
\text { Error }\end{array}$ \\
\hline In(new hires) & $\begin{array}{l}\text { No } \\
\text { Yes }\end{array}$ & $\begin{array}{l}-0.007 \\
-0.029\end{array}$ & $\begin{array}{l}(0.012) \\
(0.007) * * *\end{array}$ & $\begin{array}{l}0.070 \\
0.037\end{array}$ & $\begin{array}{l}(0.009) * * * \\
(0.006)^{* * *}\end{array}$ & $\begin{array}{c}-0.003 \\
0.039\end{array}$ & $\begin{array}{l}(0.013) \\
(0.009) * * *\end{array}$ \\
\hline $\begin{array}{l}\text { County fixed effects } \\
\text { Period effects } \\
\text { Number of observations }\end{array}$ & & & & & $\begin{array}{l}\text { es } \\
\text { es } \\
480\end{array}$ & & \\
\hline
\end{tabular}

Notes: Marginal effects are presented, along with standard errors (in parentheses). Standard errors are adjusted for the grouping of local labor market variables. The dependent variable is defined as follows: $1=$ no work, no welfare; $2=$ no work, welfare; $3=$ work, welfare; $4=$ work, no welfare. The base category in all models is 1 . All models include the variables presented in Table 2, except the unemployment rate. ${ }^{* * *},{ }^{* *},{ }^{*}$ indicate statistical significance at the $1 \%, 5 \%$, and $10 \%$ levels, respectively. 
Table 4: Multinomial Logit Estimates of Work-Welfare Combinations:

Quarterly New Hires' Earnings in Various Industries, All Women

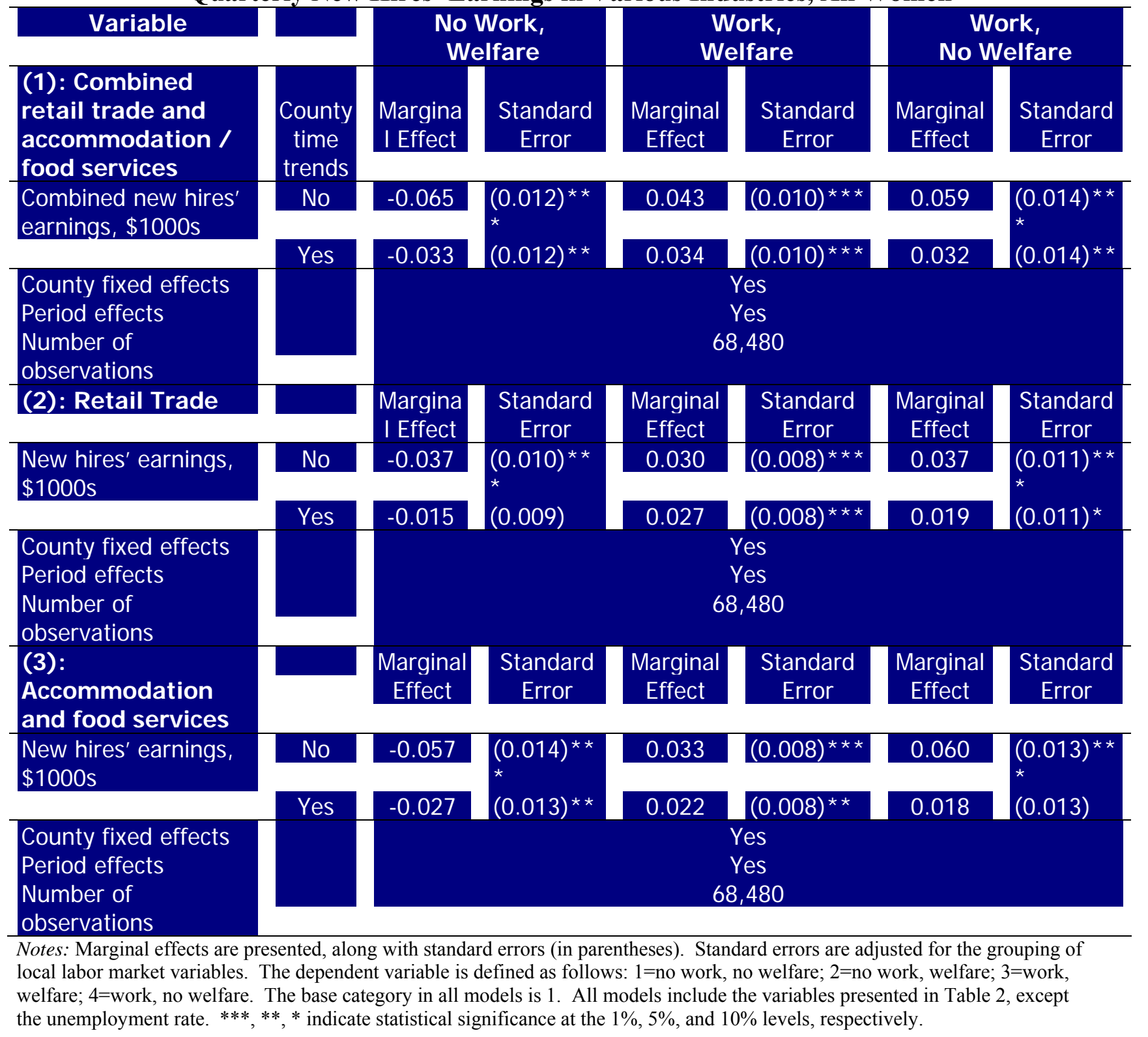


Table 5: Multinomial Logit Estimates of Work-Welfare Combinations:

Quarterly Job Flows in Various Industries, All Women

\begin{tabular}{|c|c|c|c|c|c|c|c|}
\hline Variable & & No & $\begin{array}{l}\text { lork, } \\
\text { fare }\end{array}$ & $\begin{array}{c}v \\
w\end{array}$ & $\begin{array}{l}\text { ork, } \\
\text { lfare }\end{array}$ & No V & $\begin{array}{l}\text { ork, } \\
\text { elfare }\end{array}$ \\
\hline $\begin{array}{l}\text { (1): Combined } \\
\text { retail trade and } \\
\text { accommodation / } \\
\text { food services }\end{array}$ & $\begin{array}{l}\text { Count } \\
\text { y time } \\
\text { trends }\end{array}$ & $\begin{array}{l}\text { Margina } \\
\text { I Effect }\end{array}$ & $\begin{array}{c}\text { Standard } \\
\text { Error }\end{array}$ & $\begin{array}{c}\text { Marginal } \\
\text { Effect }\end{array}$ & $\begin{array}{c}\text { Standard } \\
\text { Error }\end{array}$ & $\begin{array}{l}\text { Margina } \\
\text { I Effect }\end{array}$ & $\begin{array}{c}\text { Standard } \\
\text { Error }\end{array}$ \\
\hline Job flows, 1000 s & $\begin{array}{l}\text { No } \\
\text { Yes }\end{array}$ & $\begin{array}{c}0.0002 \\
-0.0001\end{array}$ & $\begin{array}{l}(0.0006) \\
(0.0006)\end{array}$ & $\begin{array}{c}0.00003 \\
0.0008\end{array}$ & $\begin{array}{l}(0.0005) \\
(0.0005)\end{array}$ & $\begin{array}{l}0.0007 \\
0.0006\end{array}$ & $\begin{array}{l}(0.0007) \\
(0.0007)\end{array}$ \\
\hline $\begin{array}{l}\text { County fixed effects } \\
\text { Period effects } \\
\text { Number of } \\
\text { observations }\end{array}$ & & & & & $\begin{array}{l}\text { es } \\
\text { es } \\
480\end{array}$ & & \\
\hline (2): Retail Trade & & $\begin{array}{c}\text { Margina } \\
\text { I Effect }\end{array}$ & $\begin{array}{l}\text { Standard } \\
\text { Error }\end{array}$ & $\begin{array}{c}\text { Marginal } \\
\text { Effect }\end{array}$ & $\begin{array}{c}\text { Standard } \\
\text { Error }\end{array}$ & $\begin{array}{c}\text { Margina } \\
\text { I Effect }\end{array}$ & $\begin{array}{c}\text { Standard } \\
\text { Error }\end{array}$ \\
\hline Job flows, 1000 s & Yes & 0.0004 & $\begin{array}{l}(0.0009) \\
* \\
(0.0009)\end{array}$ & $\begin{array}{l}0.002 \\
0.0005\end{array}$ & $\begin{array}{l}(0.0008) * \\
* \\
(0.0008)\end{array}$ & -0.0003 & $\begin{array}{l}(0.001)^{* *} \\
* \\
(0.0010)\end{array}$ \\
\hline $\begin{array}{l}\text { County fixed effects } \\
\text { Period effects } \\
\text { Number of } \\
\text { observations }\end{array}$ & & & & & $\begin{array}{l}\text { es } \\
\text { es } \\
480\end{array}$ & & \\
\hline $\begin{array}{l}\text { (3):Accommodatio } \\
\text { n and food services } \\
\text { lob flows. } 1000 \text { s }\end{array}$ & No & $\begin{array}{c}\text { Margina } \\
\text { I Effect } \\
0.001\end{array}$ & $\begin{array}{l}\text { Standard } \\
\text { Error } \\
(0.0008)^{* *}\end{array}$ & $\begin{array}{l}\text { Margina } \\
\text { I Effect } \\
-0.001\end{array}$ & $\begin{array}{l}\text { Standard } \\
\text { Error } \\
(0.0007)^{*}\end{array}$ & $\begin{array}{l}\text { Margina } \\
\text { I Effect } \\
-0.001\end{array}$ & $\begin{array}{l}\text { Standard } \\
\text { Error } \\
(0.001)\end{array}$ \\
\hline & Yes & -0.0007 & $(0.0009)$ & 0.001 & $(0.0008)$ & 0.002 & $(0.001)^{*}$ \\
\hline $\begin{array}{l}\text { County fixed effects } \\
\text { Period effects } \\
\text { Number of } \\
\text { observations }\end{array}$ & & & & & $\begin{array}{l}\text { es } \\
\text { es } \\
480\end{array}$ & & \\
\hline
\end{tabular}


Notes: Marginal effects are presented, along with standard errors (in parentheses Standard errors are adjusted for the grouping of local labor market variables. The dependent variable is defined as follows: $1=$ no work, no welfare; $2=$ no work, welfare; $3=$ work, welfare; $4=$ work, no welfare. The base category in all models is 1 . All models include the variables presented in Table 2, except the unemployment rate. ***, **, * indicate statistical significance at the $1 \%, 5 \%$, and $10 \%$ levels, respectively.

Table 6: Anticipated Effect of Changes in Local Labor Market Conditions and Human Capital Characteristics on Work and Welfare Participation

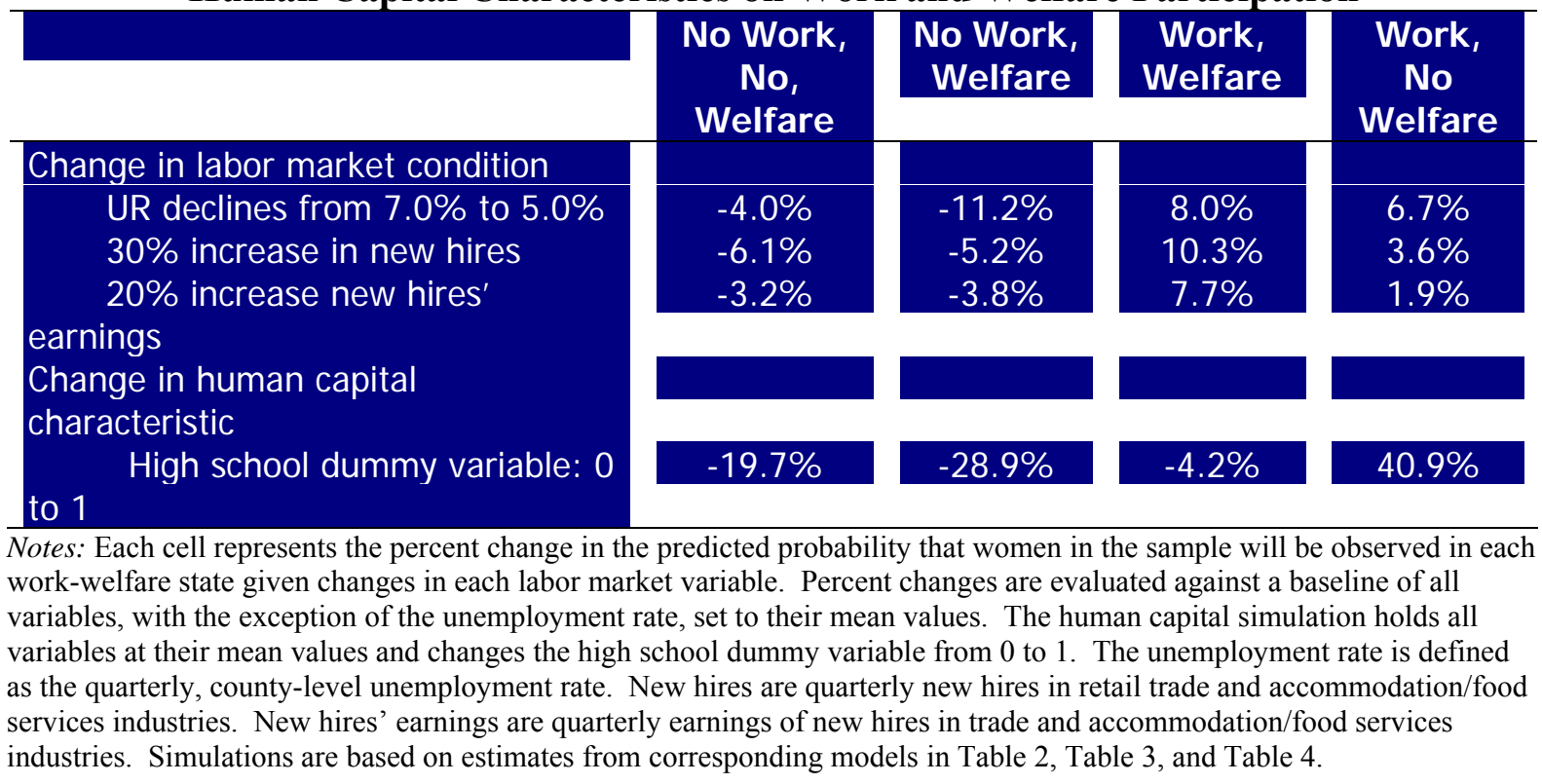


Table 7: Multinomial Logit Estimates of Work-Welfare Combinations: Retail Trade and Accommodation/Food Services Industries, by Sub-Group

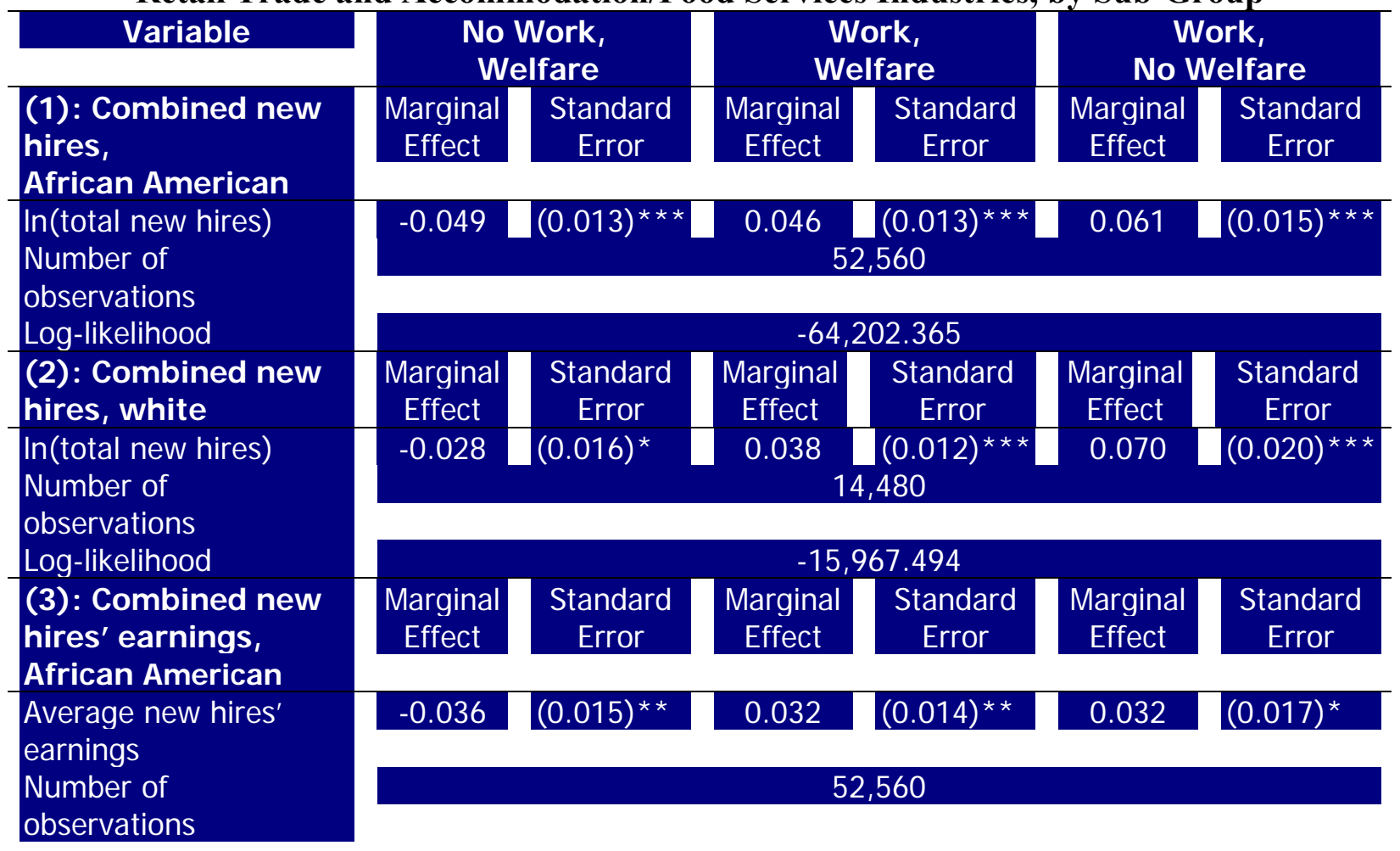




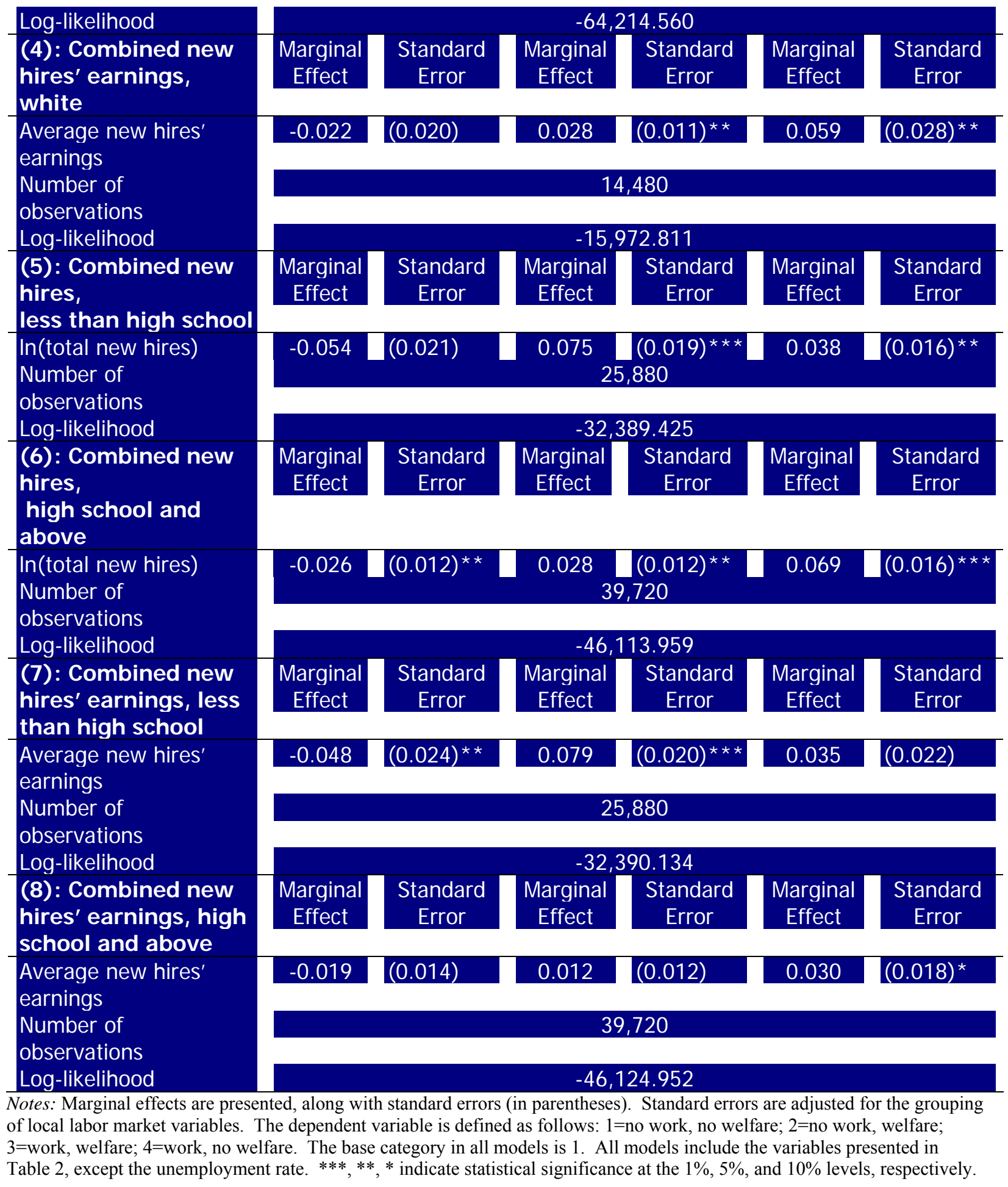


Figure 1: Quarterly Welfare and Work Participation Rates, 1996:1 - 2005:4

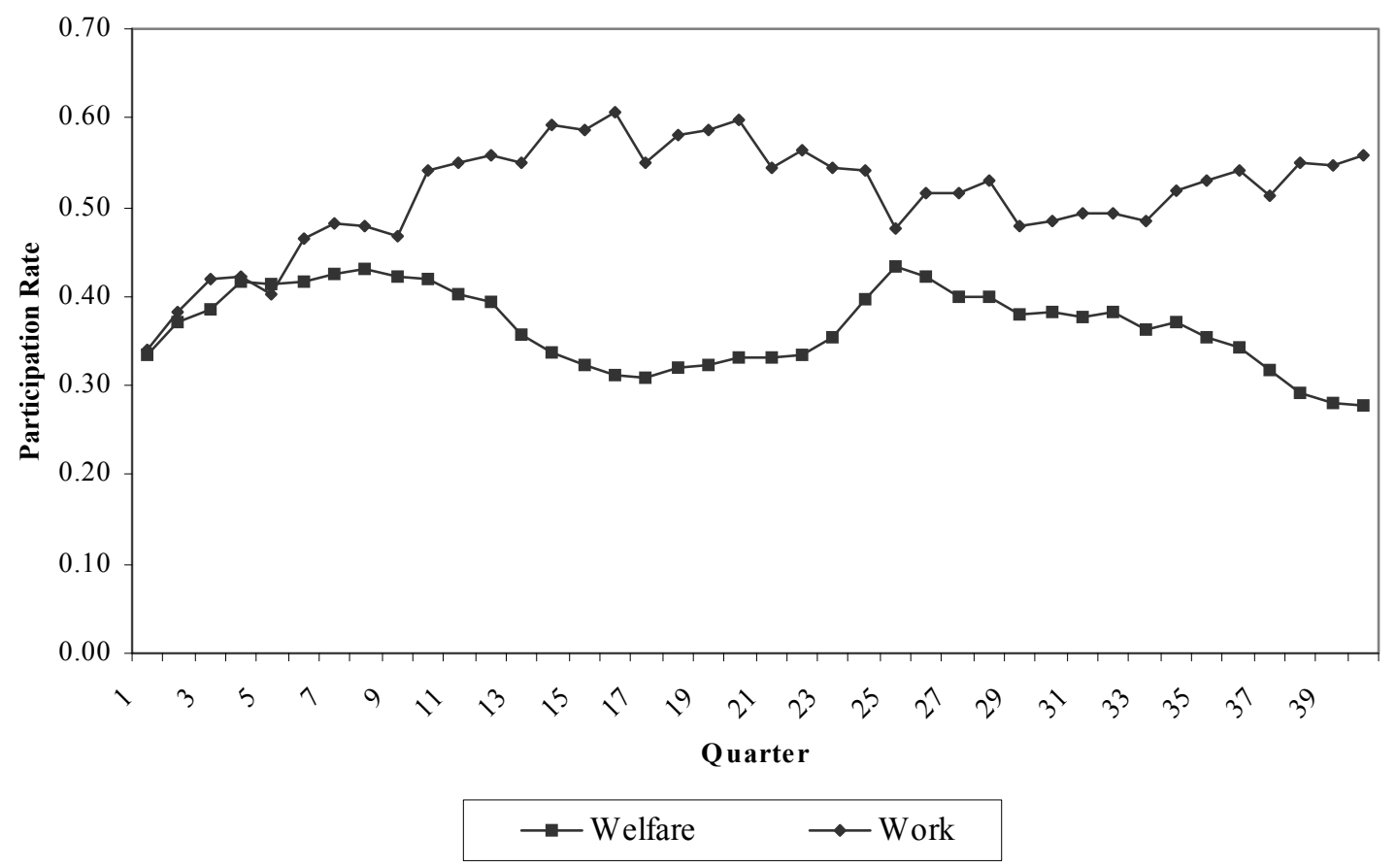

Figure 2: Quarterly Welfare and Work Participation Combinations, 1996:1 - 2005:4

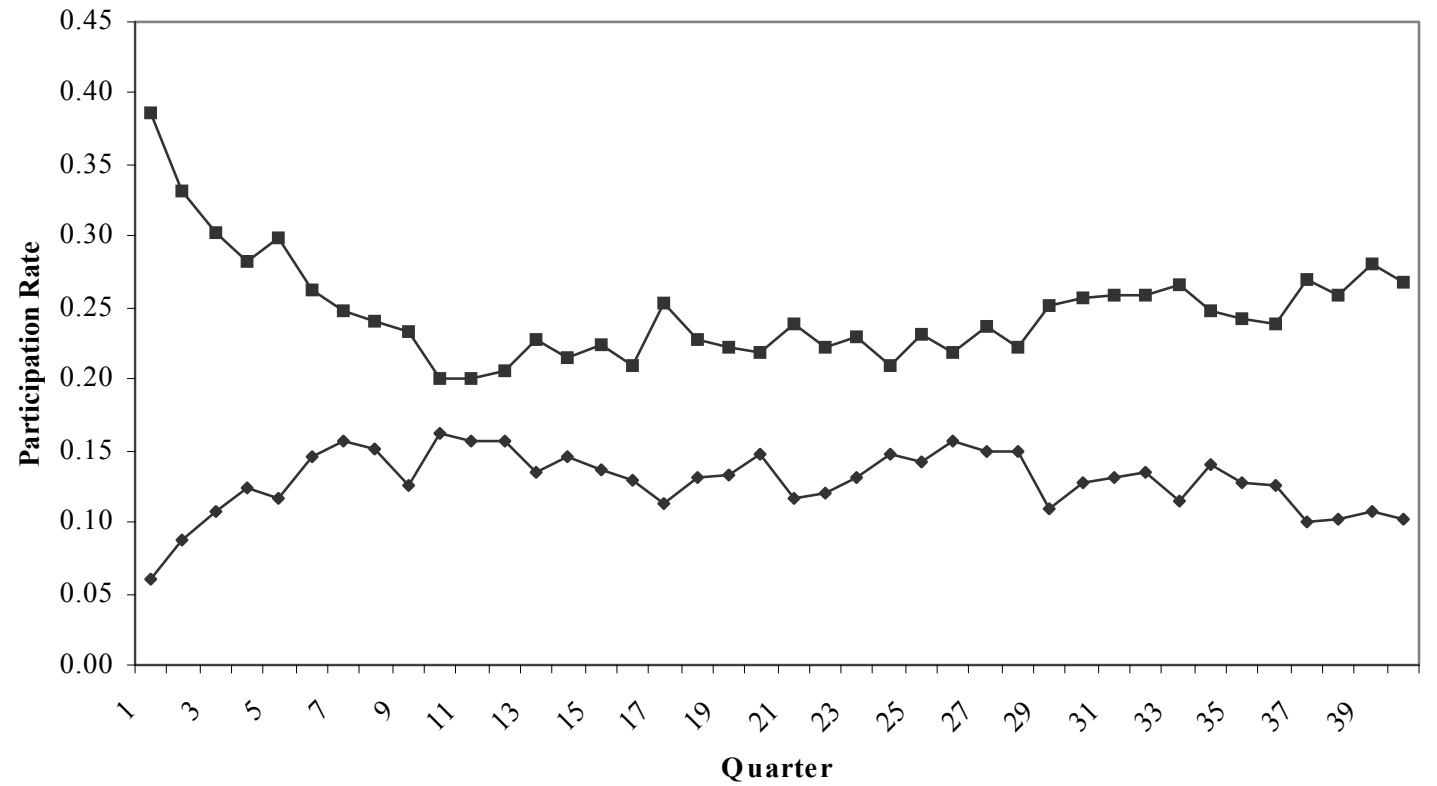

$\longrightarrow$ Work and Welfare $\rightarrow-$ No Work, No Welfare 